\title{
minutes of the council
}

\section{Minutes of the Council, Sunday, January 19, 1975, Denver Hilton Hotel, Denver, Colorado}

9:15 a.m. Present: President Johnson, President-Elect Atlas, Past President Kellogg, Secretary of the Council Shuman; Councilors Austin, Best, Bierly, Epstein, Fleagle, Fletcher, Klein, Kohler, Lindzen, McTaggart-Cowan, Pearson, Reed, Reid, Smagorinsky; Commissioners, Baum, Droessler, Roberts; Officers and Councilors starting January 20, 1975, President-Elect Hosler, Councilor-Elect Simpson; Executive Director Spengler; and Secretary-Treasurer Landrigan.

\section{AGU Representative at Council Meetings}

At the invitation of the Council, Dr. A. F. Spilhaus, Jr., Executive Director, AGU, was present. It was voted to continue this arrangement until the Council decides otherwise, with the exception that the invitation would not apply to discussions concerning ethics matters.

\section{Results of Mail Ballots to Council}

The Secretary-Treasurer reported the results of the following Mail Ballots to the Council:

a) Mail Ballot of October 16, 1974, requesting approval of Council minutes of September 19 and 20, 1974. Approved.

b) Mail Ballot of October 16, 1974, concerning the election of Dr. David K. Todd to the Council. Approved.

c) Mail Ballot of October 16, 1974, concerning the change in the name of the Cape Kennedy (Florida) Chapter to Cape Canaveral Chapter. Approved.

d) Mail Ballot of November 1, 1974, requesting approval of the $345 \mathrm{th}, 346 \mathrm{th}, 347 \mathrm{th}$ and 348 th lists of candidates for Member recommended by the Board of Admissions. Approved.

3. Actions of Executive Committee on December 9-10, 1974, and January 18, 1975

President Johnson submitted a letter to the Councilors and Commissioners dated January 17, 1975, containing a report of the Executive Committee meeting of December 9-10, 1974.

President Johnson reviewed the actions of the Executive Committee meeting held on January 18, 1975:

a) The question of a speaker for the fall Council meeting was discussed;

b) The Rossby Medal will be presented to Charles H. B. Priestley when he is in this country some time in September or early October 1975:

c) Other actions taken by the Executive Committee on January 18, 1975, will be discussed during this Council meeting.

\section{Important Issues}

President-Elect Atlas sent a memo dated January 6, 1975, to the Council entitled Initiatives in Atmospheric Science and Public Policy, to which was attached a statement containing eight suggestions with respect to this matter for consideration by the Council.

President-Elect Atlas prepared the following summary of the Council discussion on this matter:

\section{Atmospheric Sciences and Public Policy}

A Discussion of the AMS Council on 19 January 1975

Following Atlas' opening remarks Councilor Robert Fleagle voiced the view, supported throughout the discussion, that the AMS must clearly play a larger role than it has in the area of public policy. Science and technology have important consequences on the general public; and the input of the atmospheric sciences to the solution of critical national and international problems (e.g. food, energy, public safety) is becoming increasingly important. The question then is not whether to act, but what activities are most appropriate and likely to be effective.

We must, however, distinguish between "policy for science" and "science in public policy." The Society's responsibilities in these areas are moderately clear, Fleagle said. The Committee on Atmospheric Sciences of the National Academy of Sciences (NAS/CAS) has a direct responsibility for advising the government on the substance of various scientific initiatives and on general policy. In contrast, the AMS has a responsibility to the profession and discipline, and more importantly, to the public; this is more in the realm of "science in public policy" than in "policy for science." There is, of course, overlap between these responsibilities; moreover, AMS and NAS/CAS each have different constraints. Among the AMS constraints are: 1) the large professional and civil service component of the Society and 2) limited financial and personnel resources.

The problem, Fleagle noted, it how to go about discharging these responsibilities. As a first step he would look to the traditional modes of operation of the AMS, namely to publicize the issues and foster their understanding through broad discussions and meetings. Additional steps might be along the lines initiated by Atlas and those discussed below.

Councilor Eugene Bierly urged the Society to take a more activist role in public policy issues. The Congress, in particular, is in dire need of thoughtful and responsible technical advice from non-governmental scientists. He noted that a number of professional societies (e.g., American Chemical Society, American Physical Society, Institute of Electronic and Electrical Engineers) have put "fellows" on "the Hill." These are specialists who are assigned to congressional staffs for the preparation of background studies and technically-dependent legislation. The societies pay their salaries, but the fellows do not act as lobbyists for their societies. This is an important mechanism by which we can assure that the best scientific 
advice is brought to bear on forthcoming legislation, but one that is an expensive and long-term investment, for any society. Councilor-Elect Joanne Simpson suggested that we should consider using some of the distinguished and respected retired members of the Society in such a role.

Councilor Patrick McTaggart-Cowan spoke to the question of the interface between NAS/CAS and the AMS. If CAS is to remain credible, it will have to stick closely to its advisory role and avoid a strong position of advocacy. In matters of priority among disciplines, it must maintain an appearance of neutrality. He sees the AMS, on the other hand, as an advocate for the better solution of national problems and for the "care and feeding" of the profession and the science. In connection with the proposal to establish an AMS government liaison office in Washington, he has some reservations as to the effectiveness of such an operation. The first steps must be to develop a vision of the future and identify the areas in which we can be effective.

Commissioner Earl Droessler voiced the view that it is only natural that we advocate the importance of our work. Who better could recognize, appreciate, and explain the relevancy of our science to critical national problems? He thought that Bierly had provided a most attractive theme: that our major input should be to the Congress. We must be alert to the problems before the House and Senate and establish the mechanisms by which our voices can be heard. We should think carefully, he said, about working with any part of the administration. In particular, in response to Commissioner Charles Hosler's earlier suggestion that we work through NACOA (National Advisory Committee on Oceans and Atmosphere, advicory to the President and Congress but funded through the Department of Commerce), Droessler felt that NACOA's position in the government made it appear to be an arm of NOAA and not to be working in the overall interests of the science. Hosler, who is a member of NACOA, replied that NACOA was working diligently to overcome this image.

In this regard, Bierly noted that because NAS/CAS is also funded by the government it too could not be regarded as an entirely disinterested group. He observed further that government agencies were particularly sensitive, indeed sometimes hostile, to recommendations from CAS (and other groups) concerning proposed organizations of the government in implementation of scientifically related activities. The agencies, he suggested, are more interested in the various committees' views on the crucial scientific thrusts rather than on governmental issues related to their actual conduct. (Note: Sometimes, of course, agency organization impacts importantly on the effectiveness with which scientific and operational initiatives can be executed.)

Hosler observed that the credibility of the Society and its members as wise and perceptive advisors on the national scene was tied closely to the image of our profession. He was especially concerned that some of the activities of both the private and government sectors in areas such as long range forecasting, where the limitations of the predictions were not always made clear, damaged our image and general credibility.

Councilor Richard Lindzen noted that McTaggartCowan has put his finger on the key issues: we can't move ahead without a much clearer vision of the future. Unfortunately, the AMS has such a broad-based constituency, with all the conflicting needs which this implies, that we find it difficult if not impossible to set clear priorities. Perhaps, rather than seek a consensus, we should encourage and rely upon distinguished individuals to promulgate the interests of the discipline. He illustrated the point by the increased research activity which had been stimulated by recent papers and testimony by individuals before the Congress concerning the potentially disastrous effects of chlorofluoromethanes on the destruction of ozone. He emphasized that communication (with the decision-makers) was one of our most important problems. Finally, he suggested that the realities were such that we must avoid proposing across the board increases in support; rather, we must concentrate on the optimum distribution of the resources now available.

Commissioner Werner Baum felt strongly that AMS action in the public policy arena was long overdue. He noted that the educational establishment has been extremely effective both in policy setting and appropriations through various Washington offices of the academic community and especially via private contacts with key legislators. Congress is clearly the focal point for our attention. The Office of Management and Budget, while very influential, is not all-powerful. And the answer does not lie simply in putting AMS fellows on "the Hill." The effort requires an investment, but it will pay major dividends if done well. The educational establishment maintains contacts throughout Congress and government; it keeps in touch with the issues and knows the action focal points. And it draws heavily upon distinguished educators to come to Washington for private meetings with important legislators. The AMS now has an impressive stable of distinguished scientists, educators, and government officials with solid political contacts throughout the country. He argued that we should use this resource as our primary base for getting our message across. It is important to maintain close liaison with the Washington scene. A joint AMS-AGU Washington office could keep its finger on the government pulse at all times, identify the prime movers, put our Society spokesmen in contact with the right people at the right time, and push the right buttons. Short of this, Baum thought that action was improbable.

Councilor Edward Epstein suggested that because the Society had very close unofficial ties to NOAA, there was little need for further direct contacts here. NACOA could serve effectively as a conduit for information on government activities (especially in the executive branch) to the Society-it would not serve well in the other direction. But Congress lacked the kind of advice that we could offer. There is only limited communication between the various government agencies and Congress; McTaggart-Cowan added that because each agency had to make itself look good, the guidance it offered to Congress appeared biased. Councilor Joseph Smagorinsky seconded the view that Congress was in desperate need of "independent" technical guidance. Epstein also noted that the need for advice by state legislators did not appear as great as at the Federal level because state legislators seem to avail themselves more regularly of university experts. 
Councilor Fleagle, in response to doubts raised by Atlas and others concerning the impact of reports such as the NAS/CAS Friday Harbor study, thought that the latter study had indeed proposed certain basic changes in scientific direction or emphasis which in fact are occurring; it also highlighted many of the public policy issues. The Congressional intern concept appealed to him although the individual could not act as an AMS representative but only as a purveyor of sound scientific information. This would have to be regarded as a long term investment; short term payoffs were unlikely. He noted that the staff of the Senate Commerce Committee was interested in a new mechanism of "senate policy studies" which could lead to legislative hearings. An AMS intern or fellow could be most helpful in such policy studies. The Society has an enormous amount to contribute in these areas. An important step is to establish direct links with Congressional staffs.

Commissioner Walter Roberts pointed to three focal points for influencing action: 1) industrialists, 2) government and independent commissions and study groups, and 3) UN committees and conferences on critical world problems. He felt that many important industrialists are unaware of the impact of weather and climate on industry; when they become knowledgeable, they can be very influential. The Society has a tremendous untapped opportunity to influence these key decision-makers. We should also be in much closer touch with groups like the Rockefeller Commission on Critical Choices which, he believes, are largely ignorant of possible climatic impacts for example. At the level of the UN, we might also offer our services to and seek participation in various committees and conferences on food, population, etc. Roberts was astounded that he was the only atmospheric scientist at the recent World Food Conference. The forthcoming UN Conference on Human Settlements should have meteorological participation.

Councilor Smagorinsky suggested that the AMS is uniquely constituted to interface with Congress. We must, however, recognize our capabilities and limitations and distinguish between advisory and advocacy roles. He urged careful thought in defining our operating modes and bounds. Bierly noted that lobbying should not be denigrated; it is regarded as a highly respectable and necessary profession by Congress. Councilor William Klein summarized much of the discussion by suggesting that AMS action is required at four focal points: 1) the Executive branch, 2) the Congress, 3) state governments, and 4) industry.

Councilor Pauline Austin looked at the other side of the coin; i.e., how the AMS might assist various components of the profession in providing information as to prospective programs by various government agencies, the kinds of research which would be required, and the agency contact points for submitting proposals.

Fred Spilhaus, Executive Director of the AGU (who had been invited to the Council meeting by President Johnson), noted that the AGU is now concentrating primarily on the "outputs" from Congress rather than "inputs" thereto. They are moving gingerly in the input advisory role to Congress. AGU feels a need for greater interaction with government agencies and plans to use its abundant contact points in the Civil Service. He felt that they will do something in the area of Congressional in- terns. AGU anticipates that a full fledged congressional liaison program will be costly and the steps will be taken slowly and the benefits of each will be carefully weighed. The AGU "government liaison office," which was recently established, now comprises a single quarter-time person who acts mainly as an information clearinghouse. He suggested that the AGU Committee on Public Policy work closely with the AMS Planning Commission in establishing goals, plans, and activities in the area of public policy.

Following this broad and stimulating discussion, the Council approved the attached set of initiatives which had been submitted by President-Elect Atlas, Past-President Kellogg, and Councilor McTaggart-Cowan. It was decided, however, to refer the proposal for the establishment of a joint AMS-AGU government liaison office to the Planning Commission for further study.

After discussion it was voted:

1) to accept, if received, an invitation from the National Academy of Sciences Committee on Atmospheric Sciences for a joint meeting of the AMS Council with NAS/CAS in the late spring or early summer of 1975 to hear a report on "Atmospheric Sciences: Scientific Problems and Applications";

2) that the concept of establishing a joint government liaison office with the AGU (and possibly other similarly oriented societies) to provide two-way communications with the Congress and government agencies and establishing mechanisms for stimulating government action be referred to the Planning Commission;

3) that the Planning Commission be asked to study the problems of public policy implementation which President-Elect Atlas will discuss with them;

4) that the impact of the recent Cloud Physics Study Report on actions by government agencies, research institutions, and individual scientists be given consideration by President-Elect Atlas;

5) that Atmospheric Science and Public Policy be the subject of a one-day symposium at the January 1976 Annual Meeting;

6) that an appropriate amount of time be reserved at each Council meeting for full discussion of public policy issues;

7) that former Congressman Emilio Daddario, Director, Office of Technology Assessment, be invited to address the Council either at the proposed special joint meeting of the Council and NAS/CAS or at the regular meeting of the Council in October 1975. If Mr. Daddario is unable to accept, another speaker will be invited;

8) that the scheduling of local meetings dealing with the issues of meteorology and public policy by AMS chapters be referred to the Planning Commission, and also to consider if other boards or committees of AMS might follow the same policy.

\section{Introduction of Luncheon Speaker}

President Johnson introduced Dr. Francis Bretherton, President, University Corporation for Atmospheric Research, who will be the speaker at the Council luncheon.

12:00 noon, adjourned.

2:00 p.m., reconvened. 


\section{Statement on Tornado Detection, Tracking and Warning}

At the request of the Council Mr. Joseph Golden, Chairman, Committee on Severe Local Storms, discussed the Statement on Tornado Detection, Tracking and Warning, the first draft of which was sent to the Council on January 13, 1975. It was voted to adopt the Statement after several minor modifications are made by $\mathrm{Mr}$. Golden. The Statement is as follows:

\section{AMS Statement on Tornado Detection, Tracking and Warning}

\section{Introduction}

Alerting and warning the public to the existence of tornadoes involves problems of reliable detection, prompt reporting and instant credibility. A tornado "watch" is issued to alert the public to the possibility that tornadoes may develop in a specific area within a specific time interval. It is a forecast issued in advance of tornado formations. A tornado "warning" is issued only after a tornado has been sighted or a storm, suspected to include a tornado, has been indicated by radar. It warns of imminent danger or a high probability of imminent danger.

Considering detection and warning, it is important to understand some tornado "facts of life." First, the tornado is a small scale by-product of its parent thunderstorm. Fortunately, less than one percent of thunderstorms produce tornadoes. Nevertheless, many such storms must be monitored as potential tornado producers. Second, of 700 to 1200 tornadoes in the United States each year, over half are comparatively weak and shortlived. These small tornadoes, with only 1 to 3 minute lifetimes, cause relatively light damage over a path less than a mile in length and 100 yards wide. Typically wind speeds are of the order of $100 \mathrm{mph}$. The exceedingly short life cycle of such tornadoes makes issuing timely warning very difficult. On the other end of the tornado spectrum are the infrequent, devastating and often longlived large tornadoes. Although large tornadoes comprise only 1 to $5 \%$ of reported tornadoes, they account for almost all tornado injuries and deaths and for the majority of total damage. Such tornadoes may exist up to 3 hours, producing almost continuous damage paths more than 100 miles long and hundreds of yards wide. Maximum wind speeds estimated from tornado damage analyses range upward from $200 \mathrm{mph}$, but reliable actual wind speed and pressure measurements are lacking.

\section{Tornado detection and tracking}

Weather radar continues to be the primary tool in detecting and monitoring potentially severe thunderstorms, including tornado-bearing storms. The presence of a well-developed "hook-shaped" or "figure 6" echo within or on the boundary of the thunderstorm echo indicates a tornado or tornado development potential. Visual sightings frequently confirm the existence of tornadoes when parent thunderstorms display suspicious radar configurations. But many tornado-bearing storms do not have such clear-cut signatures; and some storms give false echo signatures. For these reasons and others, prompt visual sightings still provide the most reliable indication of the presence of a tornado. Law enforcement officials, trained volunteer storm spotter networks, and the alert public form the principal, indispensable source of visual sighting and reporting. Training and educational programs for such storm spotting and reporting groups should be expanded.

Once a particular thunderstorm has been identified as a tornado-producer, it must be monitored and tracked for its entire lifetime. Not uncommonly, a single parent thunderstorm produces a sequence of several tornadoes over two or more hours and over distances of 100 miles or more.

\section{Detection system development}

Steady improvements continue to be made in the $\mathrm{Na}$ tional Weather Radar Network by the addition of modern radars to replace obsolescent systems and fill gaps in the network. But these alone are unlikely to provide fully reliable tornado detection.

There are, however, four promising developments which offer hope for significant and perhaps major advances within the next few years. These are 1) improved radar displays and interpretive techniques, 2) satellite surveillance, 3) radio lightning detection (called "sferics"), and 4) Doppler radar.

\section{Radar Displays and Processing}

Increasingly, operational weather radars are being modified to display the intensity levels contoured within the thunderstorm. This modification permits the radar operator to monitor detailed pattern developments and signature echo configurations that have heretofore been masked from view. Processing, analysis, display, and dissemination in real time of the tremendous information inherent in the National Radar Network requires a system that combines radars and computers. Eventually radar and satellite storm images could be combined and displayed together.

\section{Satellite Surveillance}

The first of a series of new geostationary (stationary with respect to points on the earth) satellites was launched in May 1974. These satellites will provide 24-hour surveillance of severe storm systems over the U.S. with a higher degree of resolution and scan frequency than previously available. The impact of real-time dissemination of views of severe storm systems from a stationary vantage point will probably be in improved short-term forecasting and monitoring of the entire systems of thunderstorms.

\section{Sferics}

Over the last two decades, various investigators have suggested that tornado-bearing thunderstorms produce radio static (sferics) of a character different from that of ordinary storms. But trials of such systems have faltered on the absence of unique radio signatures and an unacceptable number of "false alarms." More refined tornadic storm sferics detection systems with direction-finding capability are being developed and tested. First results indicate that one such system detects some $60 \%$ of tornado-bearing storms, but still with too high a rate of false alarms. Nevertheless, progress to date warrants a significant continuing research and development effort. 


\section{Doppler Radar}

Unlike conventional weather radar, Doppler radar measures the speeds of raindrops in a storm both toward and away from the radar; that is, in a radial direction. Economical improved measurement techniques have recently made it possible to provide graphic displays of thunderstorm winds in real time. Recent experiments by government, military and university researchers have documented the radial velocity signature of the parent circulation associated with tornadoes. There are indications that even actual funnel clouds may be detected with special circuits to sense both large receding and approaching target velocities in the small area within the radar beam volume. Because Doppler radar can display both hook-shaped echoes seen by conventional radars and the corresponding parent circulation, and embodies a potential for identifying the tornado itself, it is generally acknowledged that Doppler radar offers the greatest hope for providing more timely and reliable tornado detection. The great promise of Doppler radar warrants major research, development, and feasibility efforts.

\section{Related efforts}

Over the long term, basic research should clarify medium scale (mesoscale) meteorological processes which initiate and maintain severe storms. Then we can expect further significant improvements in our ability to predict place and time of storm events. Final pin-pointing and warning of tornadoes will surely depend upon actual observations, but bringing the system to full alert and preparing the populace to listen for warnings must depend upon a reliable forecast at least a few hours in advance.

\section{Communications}

One of the most crucial steps in the tornado warning process is communication of the danger to the public. Tornado warnings are issued by National Weather Service offices having local forecast responsibility. Warnings normally include downstream areas that are likely to be affected ahead of the tornado-bearing storm.

Systems providing rapid distribution of severe storm and tornado warnings for local dissemination include the NOAA Weather Wire Service, the National Warning System hot line, and local public service teletypewriter circuits. In some areas, systems permit direct warnings from NWS offices to the general public. These systems include VHF-FM continuous weather radio transmissions (with tone-alert capability), direct emergency broadcasts through cooperation of local radio and television, multiple access recorded telephone announcements, and local civil defense sirens.

Local distribution and broadcasting of tornado warnings varies markedly from one part of the country to the next, and sometimes from one county to another. There are diverse community interests, resources and communication capabilities. Development of communication systems effectively disseminating storm warnings to a large general public depends on the initiative and cooperation of many groups. A uniform national warning system is not on the horizon; thus initiation of effective communications alerting systems involves cooperative effort among local NWS offices, local police, fire, and civilian defense agencies, and radio and TV stations. A prepared and concerned public can do much to promulgate such efforts and to take necessary precautions when tornado warnings are broadcast. Future progress in improved warnings and their dissemination will involve sustained research and development activity together with economic, sociological and political dedication to working out improved solutions.

\section{Statement on Mobile Homes and Severe Windstorms}

Dr. Golden discussed the Statement on Mobile Homes and Severe Windstorms which was sent to the Council on January 10, 1975. It was voted to adopt the Statement, which is as follows:

\section{AMS Statement on Mobile Homes and Severe Windstorms}

A large-scale boom in the marketing and occupancy of mobile homes has been underway in the United States since the mid-1960s. In the year 1973, almost three million mobile homes were in use as primary residences. Every year tens of thousands of new mobile homes are manufactured and marketed in all parts of the country.

With deep concern, the American Meteorological Society observes that communities of these manufactured homes have been devastated by severe windstorms in recent years. For example, about 3500 units in Corpus Christi, Texas, were demolished by Hurricane Celia in 1970.

But not only hurricanes and tornadoes destroy mobile homes. More often than not, strong, short-lived gusty winds from ordinary severe thunderstorms cause major damage and destruction. Wind gusts from such storms often reach $50 \mathrm{mph}$ or more and occur in all parts of the U.S. These gusts can cause unsecured mobile homes to be rolled and smashed. During the year ending July 1974, nearly 5000 mobile homes were damaged or destroyed by severe windstorms in the United States. The flying debris produced by unsecured mobile homes during windstorms often inflicts damage to surrounding equipment and permanent buildings, thus compounding the problem.

Death and destruction left by tornadoes, hurricanes, thunderstorm gusts and downslope mountain winds have prompted efforts to encourage both effective anchoring of mobile homes and construction of shelters by owners of mobile home parks.

Recommendations: The American Meteorological Society advises mobile home residents to evacuate their dwellings to a designated storm shelter when a severe weather warning for high winds is in effect. The Society urges that sufficient shelters be constructed at mobile home parks as a precaution against personal injury and death. Also, many lives can be saved and much damage can be prevented if mobile homes are properly anchored to the ground. Increasing numbers of states and municipalities are enacting tie-down regulations, and the Society strongly supports such action.

Additional information on proper mobile home tiedowns and shelters may be obtained from government sources through the nearest National Weather Service office or the local Emergency Planning Office; and through an industry-supported institution called Mobile Living Communication Center, P.O. Box 3431, Chicago, Illinois, 60654 . 


\section{Guidelines for Nomination of Candidates for Fellow}

A statement entitled "Nominations to the Grade of Fellow are Open" by Councilor Shuman, Chairman of the 1974 Committee on Fellows and Honorary Members, was published in the January 1975 issue of the AMS Bulletin; page 45 .

\section{Honorary Members}

The present limitation of not more than twenty living Honorary Members was discussed. It was voted to retain the limit of twenty living Honorary Members.

\section{Compendium of Meteorology}

Councilor McTaggart-Cowan presented a memorandum with respect to a new Compendium of Meteorology. It was voted:

a) to authorize a joint study by the Scientific and Technological Activities Commission and the Publications Commission:

1) to prepare a table of contents for the Compendium,

2) to illustrate the scope and usage of the Compendium by a particular example;

b) to defer the decision of approval in principle until the Council meeting in the fall of 1975.

\section{Horton Lecturer for 1976}

The Committee on Hydrology is working on a selection. It was voted that when the name of a nominee is received, a Mail Ballot will be sent to the Council.

\section{Board on Women and Minorities}

President Johnson's letter of January 10, 1975, to the Councilors and Commissioners on the proposed Board on Women and Minorities was discussed. Education and Manpower Commissioner Roberts also discussed the matter and recommended that a board of twelve members serving for three years, with four being appointed each year, be established. It was voted to establish a Board on Women and Minorities as part of the Education and Manpower Commission and to appoint the following individuals to the Board for the terms indicated:

One year, to end in January 1976
June Bacon-Bercey
Fernando Caracena
Charlotte J. Hopper
Norman A. Phillips
Two years, to end in January 1977
Margaret A. LeMone (Chairperson)
Charles E. Anderson
Joanne Simpson
Warren M. Washington
Three years, to end in January 1978
Peter A. Gilman
Paul Goodwin
Lena Loman
James Turner

The terms of reference for the Board are: to develop AMS programs to increase the participation and numbers of women and minorities in the professions embraced by the AMS by opening up educational and professional opportunities at all levels of education and ages; by establishing role models for persons seeking careers in these professions; and by informing the members of the Society and other appropriate organizations of the need for affirmative action.

\section{Appointments}

It was voted to appoint Dr. Glenn R. Hilst, Commissioner of Publications, for a second term to end in January 1978; Richard E. Orville, Commissioner of Education and Manpower, for a term to end in January 1978; and John W. Collens, III, member of the Planning Commission, for a term to end in January 1977.

It was voted to appoint the following individuals to the 1975 Committee on Fellows and Honorary Members: William H. Best, Jr., Chairman, Robert E. Dickinson, Walter Hitschfeld, Richard E. Hallgren, Robert D. Elliott.

It was voted to approve the action of the Executive Committee in appointing the following individuals to the 1975 Nominating Committee: Fred D. White, Chairman, Paul W. Kadlec, Donna W. Blake, Warren M. Washington, Douglas H. Sargeant.

It was voted to approve the action of the Executive Committee in appointing the following individuals to the 1975 Awards Committee: Cecil E. Leith, Chairman, Willard S. Houston, Jr., Richard M. Schotland, Loren W. Crow, Frederick G. Shuman.

It was voted to appoint Don H. Lucas Chairman of the Board of Education in Schools and Popular Meteorological Education for a term ending in January 1978.

It was voted to appoint Stephen Berman a member of the Board of Meteorological Education in Universities for a term to end in January 1978.

Education and Manpower Commissioner Orville will be requested to review the membership of the Commission to arrange to replace members whose terms have already expired.

Selection of the Sverdrup Gold Medal Committee was deferred.

\section{Statement on Meteorological Satellites}

The Statement on Meteorological Satellites was sent to the Council on January 10, 1975. Secretary of the Council Shuman and STAC Commissioner Droessler were requested to review the Statement in the light of the Council's discussion and to make a report thereon to the Council at its meeting to be held on January 21, 1975 .

15. Proposed Award for Outstanding Service by a Broadcast Meteorologist

Chairman Smith of the Board of Radio and Television Weathercasting submitted the following proposal for the selection criteria and procedures for selecting a person to receive the award:

\section{Award for Outstanding Service by a Broadcast Meteorologist}

Selection criteria and procedures:

Nominations for the annual broadcast Meteorologist Award can be made by any individual or group including 
the broadcaster. Nominations should be sent to the Chairman of the Board of Radio and Television Weathercasting. The Chairman will then send to the candidate a special questionnaire dealing with the award, along with information as to what supporting materials will be necessary. Since an award may be given for a number of diverse areas, supporting materials might include weathercast video tapes, special program video tapes, audio tapes, letters from listeners or viewers, special community citations, etc.

At the start of his term, the Chairman of the Board of Radio and Television Weathercasting will select four Seal of Approval holders to be members of the award subcommittee. He will designate one of the members to be the chairman of the subcommittee. No member of the award subcommittee should have any dealing, either as a business associate or competitor, with the candidate. All materials on behalf of a candidate should be sent directly to the chairman of the subcommittee.

In selecting the individual to be nominated to receive the broadcasting award, the subcommittee should carefully evaluate both the submitted questionnaire and all supporting materials. After evaluation of all the available information, each member should then give the candidates a numerical rating between $0-10$ along with short written comments on each. From this information, the chairman of the subcommittee will select the broadcaster to be nominated to receive the award.

The subcommittee selection for the broadcast meteorologist award should then be transmitted by the Chairman of the Board of Radio and Television Weathercasting to the Awards Committee of the American Meteorological Society. They then submit the recommendations to the Council for final approval.

The award is limited to not more than one individual in each year. It was voted to approve the establishment of this award.

\section{AMS Questionnaire}

A proposal for a Questionnaire to Gather Information from AMS Membership from Past President Kellogg dated January 2, 1975, was sent to the Council on January 10, 1975. It was voted to approve in principle the circulation of such a questionnaire which will be developed by a committee composed of Past President Kellogg, Prof. J. Eugene Haas, and Executive Director Spengler. The questionnaire is first to be sent to members of the AMS Council for their response before it is sent to the membership.

\section{Council Meetings}

It was voted to hold a joint meeting of the AMS Council with the Committee on Atmospheric Sciences of the National Academy of Sciences in the spring of 1975, if such a meeting can be arranged.

It was voted to hold a meeting of the Council in Boston on Thursday, October 2, and Friday, October 3, 1975 .

It was voted to hold the 1976 Annual Meeting the second, third or fourth week of January 1976 in the Northeastern part of the United States. (Philadelphia selected)

\section{Election of New Members}

It was voted to elect as Members the individuals included on the $349 \mathrm{th}, 350 \mathrm{th}, 351 \mathrm{st}$, 352nd and 353rd lists of candidates recommended by the Board of Admissions.

19. Approval of New Chapter

It was voted to authorize the organization of the Central New York Chapter.

\section{Delegation of Procedural Matters}

It was voted to have the Executive Committee examine the procedural matters of the Council and to make recommendations to the Council in October 1975 as to what matters might be delegated for action by the Executive Committee or other bodies of the AMS.

There being no further business it was voted to adjourn.

Adjourned 5:30 p.m.

$$
\begin{aligned}
& \text { Respectfully Submitted, } \\
& \text { D. F. LANDRIGAN, } \\
& \text { Secretary-Treasurer }
\end{aligned}
$$

\section{Minutes of the Council, Monday, January 20, 1975, Denver Hilton Hotel, Denver, Colorado}

5:15 p.m. Present: President Atlas, President-Elect Hosler, Past President Johnson, Past President Kellogg, and Councilors Austin, Best, Changnon, Epstein, Fleagle, Kadlec, Klein, Pearson, Shuman, Simpson, Smagorinsky; Executive Director Spengler; and Secretary-Treasurer Landrigan.

1. Nominations for Secretary of the Council were called for. It was voted to elect William H. Best, Jr., whose term on the Executive Committee also ends in January 1976, Secretary of the Council for a term of one year to end in January 1976.

2. Nominations for membership on the Executive Committee were called for. It was voted to elect Councilor Pauline M. Austin a member of the Executive Committee for the remaining year of Counciler Best's term which ends in January 1976, and Councilor Edward S. Epstein a member of the Executive Committee for a term of two years to end in January 1977.

There being no further business, it was voted to adjourn.

Adjourned 5:30 p.m.

Respectfully Submitted,

D. F. LANDRIGAN, Secretary-Treasurer

\section{Minutes of the Council, Tuesday, January 21, 1975, Denver Hilton Hotel, Denver, Colorado}

8:30 a.m. Present: President Atlas, President-Elect Hosler, Past President Johnson, Secretary of the Council Best; Councilors Austin, Changnon, Epstein, Kadlec, Kellogg, Klein, Lindzen, Reid, Simpson, Smagorinsky; Former Councilors Fletcher and Kohler; Commissioners Battan, Baum, Droessler; Executive Director Spengler; and Secretary-Treasurer Landrigan.

\section{Revised Code of Ethics}

President-Elect Hosler, Chairman, Board of Professional Ethics, presented a proposed revision of the Code of Ethics 
as requested by the Council on September 20, 1974. After discussion of the proposed Code, it was voted unanimously to place the revised Code on the ballot which will be sent to the membership in the fall of 1975 . The proposed amendment with the reasons therefore will be published in the AMS Bulletin at least ninety days before the ballots for the amendment are mailed.

\section{Proposed Statement on Meteorological Satellites}

The proposed Statement on Meteorological Satellites which was sent to the Council on January 10, 1975, was considered. It was voted l) to approve in principle this Statement, 2) to request Commissioner Droessler to consult with the Committee on Atmospheric Problems of Aerospace Vehicles on certain aspects of the Statement which were brought out during the Council's discussion and return the Statement to the Executive Committee in final form, 3) the Executive Committee will send a copy of the final Statement to the Council for suggestions prior to the release of the Statement by the Executive Committee.

\section{Place of 1976 Annual Meeting}

The place of the 1976 Annual Meeting was discussed and no great objections were raised to meeting in the Northeast. Executive Director Spengler will select the location after surveying cities and hotels for the best possibilities.
4. Invitation from the President's Committee on the $\mathrm{Na}$ tional Medal of Science to Submit Nominations

It was pointed out that Dr. Jacob Bjerknes was awarded the Medal and that the other three nominees by AMS did not receive it. A suggestion was made that consideration be given to nominating the individual who might be nominated by the AGU. President Atlas invites the members of the Council to send him suggestions for the nomination.

\section{United States Bicentennial}

The question as to how AMS might participate in the observance of the Bicentennial Anniversary of the United States was discussed. It was concluded with respect to one suggestion that no historical figure would be made an Honorary Member. Another suggestion was that some recognition might be made through a Hall of Fame. This was considered appropriate and the Council requested the Executive Committee to take the matter under advisement.

6. Numbering System to be Used in Public Policy Statements

The Council decided that in Public Policy Statements both the SI (metric) and English systems of units should be used when appropriate.

There being no further business, it was voted to adjourn.

Adjourned 10:30 a.m.

Respectfully Submitted,

D. F. LANDRIGAN, Secretary-Treasurer

\section{the american meteordogyical sociely's award tor outstanding service by a weather torecaslep}

You are invited to submit nominations for the 1976 American Meteorological Society's Award for Outstanding Service by a Weather Forecaster. Nominations for the 1976 Award, with supporting documentation, should be sent to:

\author{
Dr. Lance F. Bosart (Rm. ES 227) \\ Department of Atmospheric Science \\ State University of New York at Albany \\ 1400 Washington Avenue \\ Albany, New York 12222
}

The deadline for receipt of nominations is 15 July 1975 . Subsequently, each member of the AMS Committee on Weather Forecasting and Analysis will vote for the Awardee from an analysis of the submitted documentation. Next, a recommendation on the Awardee will be made to the AMS Awards Committee, with the final decision being made by the AMS
Council, probably in October 1975. The Award is normally presented at the AMS Annual Meeting in January.

Generally, between six and twelve nominations are received each year but only one individual is chosen for the Award. Since all nominees have outstanding credentials, the Awardee should be viewed as representative of a class of notable forecasters, anyone of whom qualifies for "the Award."

In documenting and endorsing nominees, please be sure you include enough information for the AMS Weather Forecasting and Analysis Committee to select the best choice for the coveted Award. Further, there is no restriction on nominating a candidate whose name was submitted in a previous year(s).

A description of the Award and the criteria to be followed in selecting a nominee are to be found in the August 1973 Bulletin of the AMS, page 822, and the April 1967 issue, page 318 . 